\title{
Echinicola vietnamensis sp. nov., a member of the phylum Bacteroidetes isolated from seawater
}

\author{
Correspondence \\ Olga I. Nedashkovskaya \\ olganedashkovska@piboc.dvo.ru \\ or \\ olganedashkovska@yahoo.com
}

\author{
Olga I. Nedashkovskaya, ${ }_{1}^{1}$ Seung Bum Kim, ${ }^{2}$ Bart Hoste, ${ }^{3}$ Dong Sung Shin, ${ }^{2}$ \\ Irina A. Beleneva, ${ }^{4}$ Marc Vancanneyt ${ }^{3}$ and Valery V. Mikhailov ${ }^{1}$ \\ ${ }^{1}$ Pacific Institute of Bioorganic Chemistry of the Far-Eastern Branch of the Russian Academy \\ of Sciences, Pr. 100 Let Vladivostoku 159, 690022, Vladivostok, Russia
}

\begin{abstract}
${ }^{2}$ Department of Microbiology, School of Bioscience and Biotechnology, Chungnam National University, 220 Gung-dong, Yusong, Daejon 305-764, Republic of Korea

${ }^{3}$ BCCM/LMG Bacteria Collection, and Laboratory of Microbiology, Ghent University, Ledeganckstraat 35, B-9000 Ghent, Belgium ${ }^{4}$ Institute of Marine Biology of the Far-Eastern Branch of the Russian Academy of Sciences,
Pal'chevskogo St. 17, 690032, Vladivostok, Russia
\end{abstract}

The taxonomic position of a novel marine, heterotrophic, gliding, halotolerant and light-pink-

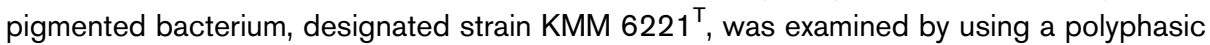
approach. 16S rRNA gene sequence analysis indicated that strain $\mathrm{KMM} 6221^{\top}$ is affiliated with the genus Echinicola, a member of the phylum Bacteroidetes, with levels of similarity of $94.7-95.0 \%$ to strains of Echinicola pacifica. Growth of strain KMM $6221^{\top}$ was observed with $0-15 \% \mathrm{NaCl}$ and at $6-44^{\circ} \mathrm{C}$. The DNA G $+\mathrm{C}$ content of strain $\mathrm{KMM} 6221^{\top}$ was $45.9 \mathrm{~mol} \%$. On the basis of

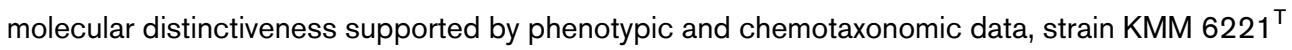
is considered to represent a novel species of the genus Echinicola, for which the name Echinicola vietnamensis sp. nov. is proposed. The type strain is $\mathrm{KMM}_{2221^{\top}}\left(=\mathrm{DSM} 17526^{\top}=\mathrm{LMG} 23754^{\top}\right)$.
The genus Echinicola was proposed to accommodate heterotrophic, Gram-negative, gliding and pigmented bacteria with menaquinone-7 as the major respiratory quinone belonging to the phylum Bacteroidetes (Nedashkovskaya et al., 2006). Strains of the only species of the genus recognized so far, Echinicola pacifica, were isolated from the sea urchin Strongylocentrotus intermedius, and differed from those of their closest relatives Algoriphagus, Hongiella, Aquiflexum and Belliella by the ability to ferment D-glucose. In this study we report the isolation and identification of a novel marine bacterium that was affiliated with the genus Echinicola on the basis of phylogenetic, phenotypic and chemotaxonomic characteristics.

Strain KMM $6221^{\mathrm{T}}$ was isolated by direct plating on a medium containing $0.5 \%(\mathrm{w} / \mathrm{v})$ Bacto peptone (Difco), $0.2 \%(\mathrm{w} / \mathrm{v})$ casein hydrolysate (Merck), $0.2 \%(\mathrm{w} / \mathrm{v})$ Bacto yeast extract (Difco), $0.1 \%(\mathrm{w} / \mathrm{v})$ glucose, $0.02 \%(\mathrm{w} / \mathrm{v})$ $\mathrm{KH}_{2} \mathrm{PO}_{4}, 0.005 \%(\mathrm{w} / \mathrm{v}) \mathrm{MgSO}_{4}$ and $1.5 \%(\mathrm{w} / \mathrm{v})$ Bacto agar (Difco) in $50 \%(\mathrm{v} / \mathrm{v})$ natural seawater and $50 \%(\mathrm{v} / \mathrm{v})$ distilled water, from seawater collected in a mussel farm located in a lagoon of Nha Trang Bay, South China Sea, Vietnam, in January 2005. After primary isolation and purification on marine agar 2216 (Difco), strains were

The GenBank/EMBL/DDBJ accession number for the 16S rRNA gene sequence of $\mathrm{KMM} 6221^{\top}$ is $\mathrm{AM} 406795$. cultivated on the same medium at $25^{\circ} \mathrm{C}$ for $48 \mathrm{~h}$ and stored at $-80{ }^{\circ} \mathrm{C}$ in marine broth (Difco) supplemented with $20 \%$ (v/v) glycerol.

DNA extraction, PCR and 16S rRNA gene sequencing were carried out as described by Vancanneyt et al. (2006). The amplification primers used were MH1 (5'-AGTTTGATCCTGGCTCAG-3') and MH2 (5' -TACCTTGTTACGACTTCACCCCA-3'), respectively hybridizing at positions 10-27 and 1507-1485 according to the Escherichia coli numbering system. Sequence data obtained were aligned with those of representative members of the phylum Bacteroidetes by using PHYDIT version 3.2 (http://plaza. snu.ac.kr/ jchun/phydit/). Phylogenetic trees were inferred by using suitable programs of the PHYLIP package (Felsenstein, 1993). Phylogenetic distances were calculated according to the Kimura two-parameter model (Kimura, 1980), and trees were constructed on the basis of the neighbour-joining (Saitou \& Nei, 1987), maximum-parsimony (Kluge \& Farris, 1969) and maximum-likelihood (Felsenstein, 1993) algorithms. Bootstrap analysis was performed with 1000 resampled data sets by using the SEQBOOT and CONSENSE programs of the PHYLIP package.

Phylogenetic analysis of the almost-complete 16S rRNA gene sequences revealed that strain KMM $6221^{\mathrm{T}}$ occupied a distinct lineage within the genus Echinicola and possessed 


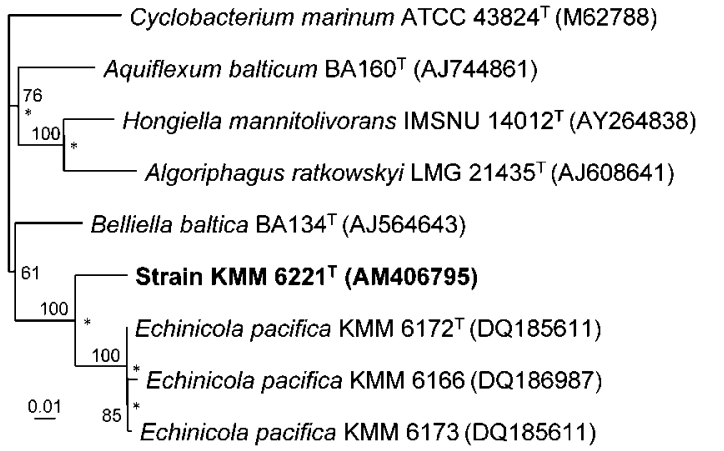

Fig. 1. Neighbour-joining tree based on 16S rRNA gene sequences of strain $\mathrm{KMM} 6221^{\top}$ and members of related genera of the phylum Bacteroidetes. The topology of the tree was not changed in trees generated with the least-squares or maximum-likelihood algorithms (not shown; asterisks indicate branches that were also recovered by using the least-squares and maximum-likelihood algorithms). Numbers at nodes indicate bootstrap percentages from 1000 resampled datasets. Bar, 0.01 substitutions per nucleotide position.

sequence similarities of $94.7-95.0 \%$ with strains of Echinicola pacifica (Fig. 1).

DNA was isolated according to the method of Marmur (1961) and the $\mathrm{G}+\mathrm{C}$ content was determined by using the thermal denaturation method (Marmur \& Doty, 1962). The G+C content of the DNA of strain KMM $6221^{\mathrm{T}}$ was $45.9 \mathrm{~mol} \%$.

Analysis of fatty acid methyl esters was carried out according to the standard protocol of the Sherlock Microbial
Identification System (Microbial ID). The predominant cellular fatty acids of strain KMM $6221^{\mathrm{T}}$ were iso- $\mathrm{C}_{15: 0}$, $\mathrm{C}_{16: 1} \omega 5 c$, iso- $\mathrm{C}_{17: 1} \omega 9 c, \mathrm{C}_{17: 1} \omega 6 c$, iso- $\mathrm{C}_{15: 0} 3-\mathrm{OH}$, iso$\mathrm{C}_{17: 0} 3-\mathrm{OH}$, summed feature 3 (comprising $\mathrm{C}_{16: 1} \omega 7 c$ and/or iso- $\mathrm{C}_{15: 0} 2-\mathrm{OH}$ ) and summed feature 4 (comprising iso- $\mathrm{C}_{17: 1} \mathrm{I}$ and/or anteiso- $\left.\mathrm{C}_{17: 1} \mathrm{~B}\right)$. Echinicola pacifica strains have a similar fatty acid composition (Nedashkovskaya et al., 2006), including the presence of summed feature 4 .

Physiological and biochemical properties of strain KMM $6221^{\mathrm{T}}$ were examined as described by Nedashkovskaya et al. (2004, 2006).

The new strain displayed many features similar to those of Echinicola pacifica (Table 1). It moved by means of gliding, was positive for oxidase, catalase and alkaline phosphatase activities, and hydrolysed starch, as found previously for strains of Echinicola pacifica. However, $\mathrm{KMM} 6221^{\mathrm{T}}$ differed in that it could not ferment D-glucose, produce hydrogen sulfide or hydrolyse agar, gelatin or Tween 40 . Production of acid from several carbohydrates and susceptibility to antibiotics could also be used to differentiate between strain KMM $6221^{\mathrm{T}}$ and Echinicola pacifica (Table 1). KMM $6221^{\mathrm{T}}$ also differs from its closest relatives by the ability to grow at up to $44{ }^{\circ} \mathrm{C}$ and with $15 \% \mathrm{NaCl}$.

Consequently, in spite of significant differences in 16S rRNA gene sequence similarity between $\mathrm{KMM} 6221^{\mathrm{T}}$ and strains of Echinicola pacifica (94.7-95\%), similarities in DNA G + C contents, fatty acid compositions and several phenotypic traits support the affiliation of the new strain with the genus Echinicola and its description as representing a novel species

Table 1. Differential phenotypic characteristics between strain $\mathrm{KMM} 6221^{\top}$ and Echinicola pacifica

All strains were positive for the following tests: gliding motility; oxidase, catalase, $\beta$-galactosidase and alkaline phosphatase activities; hydrolysis of starch; utilization of L-arabinose, D-glucose, D-lactose, Dmannose and sucrose; susceptibility to lincomycin and resistance to ampicillin, benzylpenicillin, gentamicin, kanamycin, neomycin, polymyxin B, streptomycin and tetracycline. All strains were negative for the following tests: nitrate reduction; hydrolysis of casein, cellulose (carboxymethylcellulose and filter paper), chitin and urea; acid production from D-melibiose, L-raffinose, L-sorbose, glycerol, adonitol, dulcitol, inositol and mannitol; and utilization of inositol, mannitol and sorbitol. Data for E. pacifica were taken from Nedashkovskaya et al. (2006).

\begin{tabular}{|lcc|}
\hline Characteristic & KMM 6221 $^{\text {T }}$ E. pacifica $(\boldsymbol{n}=\mathbf{3})$ \\
\hline Fermentation of D-glucose & - & + \\
Production of $\mathrm{H}_{2} \mathrm{~S}$ & - & + \\
Growth with $15 \% \mathrm{NaCl}$ & + & - \\
Growth at $44^{\circ} \mathrm{C}$ & + & + \\
Hydrolysis of agar, gelatin and Tween 40 & - & + \\
Acid production from L-arabinose, D-cellobiose, D-glucose, D-lactose, & - & - \\
D-maltose, D-mannose, L-rhamnose and DL-xylose & & \\
Susceptibility to carbenicillin, chloramphenicol, doxycycline, & + & $44-45$ \\
erythromycin and oleandomycin & 45.9 \\
DNA G + C content (mol\%) & & \\
\hline
\end{tabular}


of this genus, for which the name Echinicola vietnamensis sp. nov. is proposed.

\section{Description of Echinicola vietnamensis sp. nov.}

Echinicola vietnamensis (vi.et.nam.en'sis. N.L. fem. adj. vietnamensis referring to Vietnam, the country of origin of the type strain).

Has the following characteristics in addition to those given for the genus. Cells are $0.4-0.5 \times 1.1-2.3 \mu \mathrm{m}$. On marine agar, colonies are circular, $2-3 \mathrm{~mm}$ in diameter, convex, shiny, smooth and light pink. $\beta$-Galactosidase-positive. Does not require $\mathrm{Na}^{+}$ions or seawater for growth. Growth occurs at $6-44{ }^{\circ} \mathrm{C}$. Optimal temperature for growth is $30-32{ }^{\circ} \mathrm{C}$. Growth occurs with $0-15 \% \mathrm{NaCl}$. No flexirubintype pigments are formed. Degrades starch, but not agar, casein, gelatin, Tweens 20,40 or 80 , urea, cellulose (carboxymethylcellulose and filter paper) or chitin. Does not produce acid from $\mathrm{L}$-arabinose, $\mathrm{D}$-cellobiose, $\mathrm{D}$-fructose, D-galactose, D-glucose, D-lactose, D-maltose, D-melibiose, L-raffinose, L-rhamnose, L-sorbose, sucrose, DL-xylose, $\mathrm{N}$ acetylglucosamine, glycerol, adonitol, dulcitol, inositol or mannitol. Does not ferment D-glucose. Nitrate is not reduced to nitrite. Indole and hydrogen sulfide are not produced. Susceptible to carbenicillin, chloramphenicol, doxycycline, erythromycin, lincomycin and oleandomycin. Resistant to ampicillin, benzylpenicillin, gentamicin, kanamycin, neomycin, polymyxin B, streptomycin and tetracycline. Fatty acids accounting for $\geqslant 1 \%$ of the total are anteiso- $\mathrm{C}_{15: 0}(1.4 \%)$, iso- $\mathrm{C}_{15: 0}(20.0 \%), \mathrm{C}_{15: 1} \omega 6 c(1.2 \%)$, $\mathrm{C}_{15: 0}(1.5 \%), \mathrm{C}_{16: 1} \omega 5 c(4.9 \%)$, iso- $\mathrm{C}_{17: 1} \omega 9 c(4.4 \%)$, iso$\mathrm{C}_{17: 0}(1.0 \%), \mathrm{C}_{17: 1} \omega 6 c(4.5 \%)$, iso- $\mathrm{C}_{15: 0} 3-\mathrm{OH}(3.7 \%)$, $\mathrm{C}_{16: 0} 3-\mathrm{OH}(2.3 \%)$, iso- $\mathrm{C}_{17: 0} 3-\mathrm{OH}(10.0 \%)$, summed feature 3 (comprising $\mathrm{C}_{16: 1} \omega 7 c$ and/or iso $\mathrm{C}_{15: 0} 2-\mathrm{OH}$; $34.5 \%$ ), and summed feature 4 (comprising iso- $\mathrm{C}_{17: 1} \mathrm{I}$ and/or anteiso- $\left.\mathrm{C}_{7: 1} \mathrm{~B} ; 5 \%\right)$. The $\mathrm{G}+\mathrm{C}$ content of the DNA is $45.9 \mathrm{~mol} \%$.

The type strain, KMM $6221^{\mathrm{T}}$ (=DSM $17526^{\mathrm{T}}=\mathrm{LMG}$ $23754^{\mathrm{T}}$ ), was isolated from seawater collected in a mussel farm located in a lagoon of Nha Trang Bay, South China Sea, Vietnam.

\section{Acknowledgements}

We are most grateful to Claudine Vereecke, Public Collection Curator of the BCCM/LMG Bacteria Collection, Ghent, Belgium, for her help during preparation of the paper. This research was supported by grants from the Presidium of the Far Eastern Branch of the Russian Academy of Sciences (no. 06-04-96067), State Contract 'Scientific Schools' from the Federal Agency for Science and Innovations of the Russian Federation and Presidium of the Russian Academy of Sciences 'Molecular and Cell Biology'. I. A. B. is deeply indebted to Dr Nguyen Tac An, Director of the Institute of Oceanography, Nha Trang, Vietnam.

\section{References}

Felsenstein, J. (1993). PHYLIP (phylogeny inference package), version 3.5c. Department of Genome Sciences, University of Washington, Seattle, USA.

Kimura, M. (1980). A simple method for estimating evolutionary rates of base substitutions through comparative studies of nucleotide sequences. J Mol Evol 16, 111-120.

Kluge, A. G. \& Farris, F. S. (1969). Quantitative phyletics and the evolution of anurans. Syst Zool 18, 1-32.

Marmur, J. (1961). A procedure for the isolation of deoxyribonucleic acid from microorganisms. J Mol Biol 3, 208-218.

Marmur, J. \& Doty, P. (1962). Determination of the base composition of deoxyribonucleic acid from its thermal denaturation temperature. J Mol Biol 5, 109-118.

Nedashkovskaya, O. I., Kim, S. B., Han, S. K., Rhee, M. S., Lysenko, A. M., Falsen, E., Frolova, G. M., Mikhailov, V. V. \& Bae, K. S. (2004). Ulvibacter litoralis gen. nov., sp. nov., a novel member of the family Flavobacteriaceae isolated from the green alga Ulva fenestrata. Int J Syst Evol Microbiol 54, 119-123.

Nedashkovskaya, O. I., Kim, S. B., Vancanneyt, M., Lysenko, A. M., Shin, D. S., Park, M. S., Lee, K. H., Jung, W. J., Mikhailov, V. \& other authors (2006). Echinicola pacifica gen. nov., sp. nov., a novel flexibacterium isolated from the sea urchin Strongylocentrotus intermedius. Int J Syst Evol Microbiol 56, 953-958.

Saitou, N. \& Nei, M. (1987). The neighbor-joining method: a new method for reconstructing phylogenetic trees. Mol Biol Evol 4, 406-425.

Vancanneyt, M., Naser, S. M., Engelbeen, K., De Wachter, M., Van der Meulen, R., Cleenwerck, I., Hoste, B., De Vuyst, L. \& Swings, J. (2006). Reclassification of Lactobacillus brevis strains LMG 11494 and LMG 11984 as Lactobacillus parabrevis sp. nov. Int J Syst Evol Microbiol 56, 1553-1557. 